\title{
A Checklist of the Works of May Agnes Fleming
}

\author{
Lorraine McMullen
}

May Agnes Fleming was a popular and prolific novelist. She was born in the Portland area of Saint John, New Brunswick, I4 November I840, the daughter of Irish immigrants, Bernard Early and Mary Doherty. At the age of fifteen, she sent her first story to the popular New York Mercury. Its acceptance launched her career. She wrote for several American weeklies, as well as the local Saint John Western Recorder and Carleton Advertiser and Home Journal. Her stories lengthened to serials. Some were republished in cheap paperbacks by such publishers as Brady (New York) and Beadle and Adams (New York). Her marriage in I865 to John Fleming did nothing to slow down her writing career. In I 868 she agreed to write solely for the Philadelphia Saturday Night, and in 1873 she moved to the New York Weekly. ${ }^{1}$ By this time Fleming was doing very well financially. She had arranged for the London Journal to publish her serials, along with the New York Weekly, followed by publication in book form by Carleton (New York) and Low (London). Soon after her arrangement with the Weekly, the Fleming family, which by then included four small children, moved to Brooklyn, New York. Fleming's career ended only with her death on 24 March I880, as her last novel, Lost for a Woman, was running in the Weekly.

Fleming's novels are generally well crafted and suspenseful, with complex and ingenious plots, as befits serialized novels aiming to capture and hold reader interest, and are characterized by gothic and melodramatic elements. In her later novels, the plots are more realistic and the characters more plausible; the gothic elements diminish while the mystery and romance remain.

Because of her immense popularity, Fleming's works went through many editions during her lifetime and in the thirty years following her death. Some of these editions were authorized, some were not. Titles were sometimes changed. In the course of my research on Fleming, I found it frequently necessary to revise my list of her works. It therefore seemed that it would be useful to librarians and other scholars to make this checklist available. As well as Fleming's novels, this list includes what short fiction 
I have been able to locate. As her short fiction appeared in a number of ephemeral publications, this list is by no means complete.

Most of Fleming's novels were first published in serial form in popular story papers of the day. The earliest story which I was able to locate appeared in 1857 . From that date until I 868 , she published in a number of papers, using the pseudonym Cousin Mary Carleton for stories published in The Western Recorder and Carleton Advertiser and Home Journal, subsequently The Western Recorder and Weekly Herald (Saint John, New Brunswick). Elsewhere she used the pseudonym Cousin May Carleton. Before her marriage in $\mathrm{r} 865$, a novel in book form occasionally appeared under her own name, M.A. Early. When in 1868 she agreed to write solely for the Philadelphia Saturday Night, she published as Mrs. May Agnes Fleming. From that date it is possible to be more precise about the first date of publication of her fiction. According to Henry Morgan's Bibliotheca Canadensis, Fleming published stories in the Pilot (Boston), the Metropolitan Record (New York), and the Ledger (New York). I was unable to locate stories by her in the Pilot, and neither the Metropolitan Record nor the Ledger is available for the years during which she is likely to have published in them. I have included in this checklist the titles listed by Morgan as having appeared in these three papers.

Fleming was a prolific writer, but not quite so prolific as a preliminary list of her titles seems to indicate. Because of their popularity, her novels were frequently reprinted, many under two or more different titles. At times they were pirated by British and Canadian publishers and again given different titles. Fleming complained about the pirating of her works by Canadian publishers, and some of her novels did appear in paperback series issued by Hunter, Rose and by the Toronto News Company.

Before her agreement with the London Journal, that paper had pirated two of her stories. The Heiress of Glen Gower, published in Saturday Night in I869, appeared the same year, anonymously, in the London Journal, as The Sister's Crime; Or, The Heiress of Ravensdale. Who Wins? A Love Story, published in Saturday Night in I870, appeared that year in the London Journal, again anonymously, as The Mystery of Mordaunt Hall. In both stories, the London Journal changed the locales and the names of the characters. On contracting to publish Fleming's stories, the London Journal revealed her authorship of these two anonymously published stories, noting the fact with the first instalment of $A$ Wonderful Woman on 6 July I 872. The London Journal, now interested in protecting its author from the piracy of which it had itself been guilty, warned of the story then beginning serialization: '(N.B. - This story is copyright. Proceedings will be taken in case of infringement).'

I am convinced that four novels sometimes ascribed to Fleming were 
not written by her, and have not included them in my checklist. Madge Wylde, the Young Man's Ward; Or, Light and Shadows of Orphan Life (186I) is assigned by the National Union Catalogue to Arthur Townley. On the first page of the text at the New York Public library, Fleming's name has been inscribed in pencil. There are several reasons for stating that Arthur Townley is not a Fleming pseudonym. When Townley's first novel, Clifton, was published, Fleming was twelve years old. As well, the style and subject matter of Madge Wylde are not characteristic of Fleming. Another Townley novel, Hates and Loves; Or, The Lesson of Four Lives (1863), is also sometimes ascribed to Fleming. ${ }^{2}$ The Adopted Daughter; Or, The Trials of Sebra, A Tale of Real Life, published anonymously (Montreal: Lovell, I 863) is ascribed to Fleming in a pencilled note in a copy of the book in the Harriet Irving Library at the University of New Brunswick. As far as can be ascertained, Fleming's stories were never published in book form with a Canadian publisher except in pirated editions. The sanctimonious and moralistic tone of The Adopted Daughter is quite unlike anything of Fleming's that I have read. On the title page of the copy of She Might Have Done Better (Toronto: Rose Belford, n.d.) at the Thomas Fisher Rare Book Library, the name of May Agnes Fleming has been inscribed. The setting of this novel is a Canadian house on a small lake above Lake Ontario, a setting that, to my knowledge, Fleming has not used elsewhere. The novel contains exhaustive descriptions of characters and longwinded speeches by them, not at all characteristic of Fleming's style. I have not located this text elsewhere under this or any other title, as would be the case had Rose Belford pirated it from its original American publisher. While there remains a slight possibility that this is a very early Fleming novel serialized first in an ephemeral publication, it seems highly unlikely.

Patricia Kemball (Toronto: Rose Belford, I 882) appears in the checklist, with a question mark. I know of only one copy of this novel, in the Library of Massey College, University of Toronto. ${ }^{3}$ While Fleming's authorship cannot be completely discounted, it is extremely doubtful. The style is more discursive than Fleming's, with more philosophizing and more description of feelings, conflicting attitudes, etc. There are details about English life and customs which we do not find in novels of English high life by Fleming, who had never been to England. There is criticism of the rigid British class structure, which is also uncharacteristic of Fleming.

The checklist lists the novels and stories chronologically, and includes all the titles I have located and, where available, dates of serialization and date of first publication in book form. Every attempt has been made to include all titles under which a work appeared. It should be noted that some titles listed are for the second half of a novel, in which case the first half is published under the original title. This splitting of novels into two 
differently titled books occurred some years after Fleming's death, when copyright was held by her daughter, Maude A. Fleming. In some cases, too, it will be noted that a novel is serialized under different titles in the New York Weekly and the London Journal, and that a book may appear immediately after serialization with a completely different title from the serialized version.

Such variation in titles, especially in editions published after Fleming's death, has led some critics to assume that many novels by other authors were published under her name to capitalize on her popularity. Research for this checklist indicates that this is not so. Many of the novels published after her death can be traced to earlier publication dates, and most were published by her own publishers: the New York Weekly, Street and Smith, William Carleton, and later, Dillingham, which took over the Carleton list.

I acknowledge with thanks the ssH R C C research grant and leave fellowship which allowed me to pursue my research on May Agnes Fleming, and wish to thank Jean-Marie Brière, Head of Research and Systems, National Library of Canada, and Bruce Whiteman, Department of Rare Books and Special Collections, McLennan Library, McGill University, for advice concerning format.

NOTES

I I am grateful to the Free Library of Philadelphia for information concerning the Fleming novels serialized in Philadelphia Saturday Night, the New York Public Library for access to their copies of the New York Weekly and the Sunday Mercury, and the British Library for access to the London Journal. I wish to express special thanks to Richard Landon and the librarians of the Thomas Fisher Rare Book Library, University of Toronto, for their helpfulness, including allowing me generous access to their fine collection of May Agnes Fleming novels.

2 Sect See Albert Johannsen, The House of Beadle and Adams and Its Dime and Nickle Novels, 2 vols. (Norman, Oklahoma: University of Oklahoma, I962), 11: 37-8, who agrees that Arthur Townley is not a May Agnes Fleming pseudonym.

3 I am grateful to Desmond Neill, Librarian, Massey College, University of Toronto, for allowing me generous access to this text. 


\section{7}

'The Last of the Mountjoys.' Sunday Mercury (New York), I857.

Reprinted in The Old Red House Among the Mountains, ed. Mary

Jane Holmes. New York: Leisure Hour Library (\#350), I90I, pp. 27-32. 'The Lady's Choice.' The Western Recorder and Carleton Advertiser and Home Journal (Saint John, New Brunswick), 28 November I857, p. I.

\section{9}

'Zion: An Old Man's Tale.' The Western Recorder and Carleton Advertiser and Home Journal (Saint John, New Brunswick), 23 April I 859, pp. I-2, and 30 April I859, p.2.

'Little Lilly.' The Western Recorder and Weekly Herald (Saint John, New Brunswick), 2 I May I859, pp. I-2.

'Nora; Or, Love and Money.' Sunday Mercury (New York), 26 June I 859, p. 3 .

'Love's Young Dream.' Sunday Mercury (New York), 20 November I 859 , p. 2.

'The Rover Chief.' Sunday Mercury (New York), I 859.

1860

'The Wages of Sin.' Sunday Mercury (New York), I9 February I860, p. 6. 'Ned's Wife and Mine.' Sunday Mercury (New York), 8 April I86o, p. 2. 'Maggie's Love.' Sunday Mercury (New York), 23 September i 860, p. 2. 'The Philopene.' Sunday Mercury (New York), 7 October I860, p. 2. 'Gipsy Gower.' Sunday Mercury (New York), I860.

'Three Cousins.' Metropolitan Record (New York), I 860.

1861

Edith Percival. In New York Mercury, I 86I. New York: Dillingham, I893, 330 p. Published as The Hermit of the Cliffs. New York: F.M. Lupton, c. I865. Second half published as Caught in the Snare. New York: Street and Smith. c. I893, 2 I 9 p.

Silver Star; Or, The Mystery of Fontelle Hall. A Story of New Jersey in the Olden Time. New York: Brady, I86I, I42 p. In Sunday Mercury (New York), I863. Published as The Dark Secret. New York: Hurst, I875, 36I p. Published as Pride and Passion. New York: Dillingham, c. I $878,416 \mathrm{p}$.

Sybil Campbell; Or, The Queen of the Isle. In Sunday Mercury (New York), I86I. New York: Beadle, I86I, I27 p. Also New York: Brady, I 863. Published as An Awful Mystery. New York: Beadle, I 875. Published as The Queen of the Isles; Or, The Campbell's Curse. Toronto: E.E. Sheppard, I886, 400 p. Published as The Queen of the 
Isle; Or, Sybil Campbell's Love. Chicago: Donahue, c. I904, 270 p. 'Georgia's Doom.' Metropolitan Record (New York), I86I.

\section{2}

'Accursed.' Sunday Mercury (New York), 9 February I862, p. 2.

'Ellie Moore.' Pilot (Boston), I 862.

Erminie; Or, The Gypsy's Vow. In Sunday Mercury (New York), r 862.

'Hagar Clyde.' Metropolitan Record (New York), I 862.

'For Spite.' Sunday Mercury (New York), 27 April i862, p. 2.

'A Traveller's Vexations.' Sunday Mercury (New York), I7 July I862, p. 3.

Victoria; Or, The Heiress of Castle Cliffe. In Sunday Mercury (New York), I863. In Philadelphia Saturday Night, 23 October I 868-69.

New York: Brady, I 864. Published as Unmasked. New York: Beadle, I870. Published as The Heiress of Castle Cliffe. New York: Federal Book Co., c. I 875, 320 p. Published as Wedded for Pique. New York: Dillingham, I897, 302 p. Published as The Heiress of Castle Cliffe; Or, Off With the Old Love. New York: Street and Smith (Eagle Series, \#309|, c. I904. Published as Vivia, the Heiress of Castle Cliffe.

London: James Henderson, n.d.

1863

Erminie; Or The Gypsy Queen's Vow. A Tale of Love and Vengeance.

New York: Brady, I863, I 58 p. Published as The Gypsy Queen's Vow; Or, The Victim of Fate. New York: Hurst, I 865. Also New York:

Beadle, I869, I 58 p. Published as Maud Percy's Secret. New York:

Carleton, c. I884, $432 \mathrm{p}$.

'Fairy May.' Pilot (Boston), I863.

La Masque; Or, The Midnight Queen. New York: Brady, I863, 396 p. In Sunday Mercury (New York), i 864. Published as The Midnight

Queen. New York: Beadle, I876. Also New York: Dillingham, I888.

'My Folly.' Sunday Mercury (New York), 5 July i 863, pp. 2-3.

The Sisters of Torwood. In Metropolitan Record (New York), I863. Also

New York: Street and Smith, I 890.

\section{4}

'Hazelwood.' Sunday Mercury (New York), i 864.

'New Year's Eve.' Metropolitan Record (New York), I 864.

The Twin Sisters; Or, The Wronged Wife's Hate. New York: Beadle and

Adams, I864, 97 p. Also New York: Starr, I869. Published as The Rival Brothers. New York: Beadle, 1875. Published as $A$ Wronged Wife. New York: Dillingham, I883. 
1865

The Hermit of the Cliffs. New York: F.M. Lupton, c. I865. See Edith Percival, I86I.

'Miriam.' Sunday Mercury (New York), I 865.

'Natalie Marsh.' Sunday Mercury (New York), I865.

1866

Eulalie; Or, A Wife's Tragedy. In Sunday Mercury (New York), I 866.

New York: Brady, I866, I 3 p. London: Low, I88 I. Published as $A$ Wife's Tragedy. New York: Carleton, I88I, 43 I p. Also Toronto: Rose Belford, I $88 \mathrm{I}$.

1867

'Miss Ingersoll's Story.' Sunday Mercury (New York), 6 October I 867, pp. 2-3.

'Sir Gervais.' Sunday Mercury (New York), 20 October I867, pp. 2-3.

\section{8}

Baronet's Bride. In Philadelphia Saturday Night, 6,2 (3 October I 868) 6, I 4 (26 December I 868). Published as The Baronet's Bride; Or, A Woman's Vengeance. Chicago: M.A. Donahue, r868, 250 p. Also New York: Munro, I 892. Published as The Heir of Kingsland Court; Or, The Baronet's Bride. London: James Henderson, c. I867.

1869

The Heiress of Glengower. In Philadelphia Saturday Night, 6, I 8 (23 January I 869) - 6,30 (I7 April I 869). Published as The Heiress of Glen Gower; Or, The Hidden Crime. Chicago: Donahue, c. I869, 25 I p. Also New York: Munro, I 892. Published anonymously as The Sister's Crime; Or, The Heiress of Ravensdale. In London Journal, I 5 May I 869 - I September I 869.

Estella's Husband. In Philadelphia Saturday Night, 6,3 I (24 April I869) - 6,44 (24 July I 869). Published as Estella's Husband; Or, Thrice Lost, Thrice Won. New York: Munro, c. I869, 29 I p. Also New York: Munro, I89r. Published as Thrice Lost, Thrice Won; Or, Estella's Husband. New York: Street and Smith, c. I892, 253 p.

Sybilla's Marriage. A Woman's Story. In Philadelphia Saturday Night, 6,5 I (I I September I 869)-7,6 (30 October I 869).

The Sister's Crime; Or, The Heiress of Ravensdale. See The Heiress of Glengower, I869. In London Journal, i 869.

The Gypsy Queen's Vow; Or, The Victim of Fate. New York: Beadle, I869, I 58 p. See Erminie, I 863. 
The Unseen Bridegroom; Or, Wedded For A Week. New York: Munro, I869, 2 I 5 p. Also New York: Munro, I892. Published as The Unseen Bridegroom. New York: Surprise Library, c. I900.

1870

Lady Evelyn. In Philadelphia Saturday Night, 7, I 5 (I January 1870) 7,30 (I6 April r870). Published as Lady Evelyn; Or, The Lord of Royal Rest. Chicago: Donahue, c. I870, 228 p. Also New York: Street and Smith, I 899 .

Who Wins? A Love Story. In Philadelphia Saturday Night, 7,30/16 April I 870) - 7,44 (23 July I 870). New York: Surprise Library, n.d. Published as Who Wins? Or, The Secret of Monkswood Waste. New York: Munro, c. I870, 225 p. Also New York: Munro, I895. Published anonymously as The Mystery of Mordaunt Hall. In London Journal ( 6 July - I November I 870).

The Mystery of Mordaunt Hall. In London Journal ( I 6 July - I November I 870). Published anonymously. See Who Wins? A Love Story, I 870.

Unmasked. New York: Beadle, I870. See Victoria; Or, The Heiress of Castle Cliffe, I 862 (?).

1871

Magdelen's Vow. In Philadelphia Saturday Night, 8,22 (I 8 February I 87I) - 8,37 (3 June I87I). New York: Munro, c. I87 I, 286 p. Also New York: Munro, 1893.

Which Will She Marry? In Philadelphia Saturday Night, 9,6 (29 October I 87I) - 9,20 (3 February I872).

1872

A Wonderful Woman. In New York Weekly, i872. In London Journal 16 July r $872-28$ December I872). New York: Carleton, I873, 544 p. First half published as A Wonderful Woman; Or, Rose O'Donnell's Secret. New York: Street and Smith, I906. Second half published as Mystery of Bracken Hollow. New York: Street and Smith, I9I 5.

A Leap in the Dark; Or, Wedded Yet No Wife. In New York Weekly, I 872-73. Published as Guy Earlscourt's Wife. New York: Carleton, I873; London: Low, I 872. Published as The Paths of Love; Or, A Leap in the Dark. London: James Henderson, n.d.

1873

Guy Earlscourt's Wife. New York: Carleton, I873. See A Leap in the Dark; Or, Wedded Yet No Wife, I872-73.

A Terrible Secret. In New York Weekly, i873. In London Journal, 3 I May 
I873-8 November I873. New York: Carleton, I874, 410 p. Also New York: Dillingham, I 897 . Second half published as When Tomorrow Came; Or, The Cost of Jealousy. New York: Street and Smith (Eagle Series), I901.

1874

Norine's Revenge. In New York Weekly, i 874. In London Journal, I I April I 874-20 June I 874. New York: Street and Smith, n.d. Also New York: Dillingham, I888. See also Norine's Revenge and Sir Noel's Heir, I 875.

A Mad Marriage. In New York Weekly, i874-75. In London Journal, I 5 August I 874 - I6 January I875. New York: Carleton, I875, 459 p. Second half published as Woman Without Mercy; Or, A Heart of Stone. New York: Street and Smith (Eagle Series), c. I904.

\section{5}

One Night's Mystery. In New York Weekly, I875. In London Journal, 22 May I875 - 4 December I875. New York: Carleton, c. I876, 443 p. Also New York: Dillingham, I 897.

An Awful Mystery. New York: Beadle, I875. See Sybil Campbell; Or, The Queen of the Isle, I86I.

The Dark Secret. New York: Hurst, I875. See Silver Star; Or, The Mystery of Fontelle Hall, I86I.

The Heiress of Castle Cliffe. New York: Federal Book Co., c. I875, 320 p. See Victoria; Or, The Heiress of Castle Cliffe, I 862 (?).

Norine's Revenge and Sir Noel's Heir. New York: Carleton, I875. Norine's Revenge, 239 p.; Sir Noel's Heir, I23 p. Also published separately.

The Rival Brothers. New York: Beadle, r875. See The Twin Sisters; Or, The Wronged Wife's Hate. New York: Beadle, I 864.

1876

In Golden Bondage. In London Journal, i 8 March I876-24 June 1876. See Kate Denton; Or, Captain Danton's Daughters, I876.

Kate Danton; Or, Captain Danton's Daughters. In New York Weekly, I 876. New York: Carleton, I876; London: Low, I876, 436 p. Published as In Golden Bondage. In London Journal, i 8 March I876-24 June I876. Second half published as Proud as a Queen; Or, Kate Danton the Beautiful. New York: Street and Smith, c. I904.

The Midnight Queen. New York: Beadle, I876. See La Masque; Or, The Midnight Queen, I863.

Silent and True; Or, A Little Queen. In New York Weekly, I876-77. New 
York: Carleton, I877, 460 p. Published as A Little Queen. In London Journal, 23 September I876 - Io March I877. Second half published as A Treasure Lost. New York: Street and Smith (Eagle Series), I904.

A Little Queen. In London Journal, 23 September I876 - Io March I 877. See Silent and True; Or, A Little Queen, I876-77.

1877

One False Step. In London Journal, 7 July I877 - I8 August I877. Also published as The Ghost of Riverdale Hall. New York: Lupton (The Armchair Libraryl, I895, $62 \mathrm{p}$.

Shaddeck Light! In New York Weekly, I877-78. Published as The Forced Marriage in London Journal, 3 November I877 - I3 April I878.

Published as The Heir of Charlton. New York: Carleton, I879, 396 p.

Also New York: Carleton, I905.

The Forced Marriage. In London Journal, 3 November I877 - I3 April I878. See Shaddeck Light! I877-78.

\section{8}

Carried By Storm. In New York Weekly, I878-79; in London Journal, I4 December I878 - 7 June I 879. New York: Dillingham, I879, 400 p. Second half published as Love's Dazzling Glitter. New York: Street and Smith, c. I904.

Pride and Passion. New York: Dillingham, I878. See Silver Star, r861.

1879

A Secret Sorrow. In London Journal, 5 July I 879-20 September i 879. In New York Weekly. Published as The Secret Sorrow. New York: Ogilvie, I88I, 34I p. Published as A Fateful Abduction; Or, The Secret Sorrow. New York: Dillingham, c. I907.

The Heir of Charlton. New York: Carleton, I879, 396 p. See Shaddeck Light! I 877-78.

Lost For a Woman. In New York Weekly, r879-8o. In London Journal, I7 January I $880-26$ June I880. New York: Carleton, I88o, 456 p. Last half published as His to Love or Hate. New York: Street and Smith, I907.

\section{1}

A Changed Heart. New York: Carleton; London: Low, I88I, 480 p. Published as A Changed Heart; Or, A Sweet Little Lady. New York: Dillingham, I897. Also New York: Street and Smith, c. I909. Fated to Marry; A Night of Terror; Kathleen. New York: Ogilvie, I88I. 
The Three Cousins, and One Summer Month. New York, I88I. See 'Three Cousins,' I 860.

A Wife's Tragedy. New York: Carleton, I88I, 43 I p. See Eulalie; Or, A Wife's Tragedy, 1866.

1882

'A Dark Conspiracy.' Published with Norine's Revenge and Sir Noel's Heir. New York: Carleton, I882, pp. 379-92.

'For Better for Worse.' Published with Norine's Revenge and Sir Noel's Heir. New York: Carleton, I882, pp. 393-402.

Patricia Kemball. Toronto: Rose-Belford, I882. (Authorship uncertain).

1883

'The Child of the Wreck.' In Twelve Complete Novelettes by Popular Authors. New York: F.M. Lupton, I5 September I 883, pp. 49-54.

Sharing Her Crime. New York: Dillingham, c. I882, 384 p. London: Low, I 883 .

A Wronged Wife. New York: Dillingham, I883. See The Twin Sisters;

Or, The Wronged Wife's Hate, i 864.

1884

Maud Percy's Secret. New York: Carleton, c. I884. See Erminie; Or, The Gipsy Queen's Vow, I863.

1886

The Actress' Daughter. New York: Carleton, I886, 394 p.

Queen of the Isle. New York: Dillingham, I886. See Sybil Campbell; Or, The Queen of the Isle, I86I.

'The Mystery of Blackwoods.' In Leisure Hour Library, New Series, I.I I9. New York: Lupton, I 886.

1887

The Heir of Kingsland Court; Or, The Baronet's Bride. London: James Henderson, c. I887. See The Baronet's Bride, I 868.

1888

Uncle Fred's Visit and How it Ended. London: Mowbray, I888, 5 I p.

The Virginia Heiress. New York: Street and Smith, I 888, 239 p.

1891

Married For Money and Other Stories. New York: Ogilvie, I891, 246 p. 
'Married for Money.' See 'Nora; Or, Love and Money,' I 859. 'The Old Story;' 'How I Won a Husband;' 'A Merry Bridal Eve;' 'A Modern Hebe.'

Married For Money and Other Stories. New York: Ogilvie, I891.

'Married for Money.' See 'Nora; Or, Love and Money,' I 859. 'The Old Story; 'How I Won a Husband.'

A Pretty Governess and Other Stories. New York: Ogilvie, I 89I, 2 I 8 p.

'A Pretty Governess;' 'The Dead Heart;' 'Counting One's Cousins;' 'A Tale of the Past;' 'A Merry Christmas;' 'Magdalene;' 'The Island Witch;' 'A Bright Widow;' 'A Woman's Love;' 'The Burning of the Ferry.'

1892

Sir Noel's Heir. New York: Lupton, I 892, I 23 p. See also Norine's

Revenge and Sir Noel's Heir, I875.

Thrice Lost, Thrice Won; Or, Estella's Husband. New York: Street and Smith, c. I892. See Estella's Husband, r869.

1893

Caught in the Snare. New York: Street and Smith, c. I893. See Edith Percival, I86I.

1894

A Pretty Governess. New York: Ogilvie, I 894. Contains the first eight stories in A Pretty Governess and Other Stories, I89I.

1895

The Ghost of Riverdale Hall. New York: Lupton (The Armchair Library), I 895, 62 p. See One False Step, I 877.

1897

Wedded for Pique. New York: Dillingham, I897, 302 p. See Victoria; Or, The Heiress of Castle Cliffe, I 862 (?).

'Why They Parted.' In Happy Hours Library. A Semi Monthly Magazine for the People, No. 76 (I 5 February I 897), pp. 59-60.

1901

When Tomorrow Came; Or, The Cost of Jealousy. New York: Street and Smith (Eagle Series), I 9or. Second half of $A$ Terrible Secret. See $A$ Terrible Secret, 1873 . 
1904

Love's Dazzling Glitter. New York: Street and Smith, c. 1904. See

Carried By Storm, I878-79.

Proud as a Queen; Or, Kate Danton the Beautiful. New York: Street and Smith, c. I904. Second half of Kate Danton; Or, Captain Danton's Daughters. See Kate Danton; Or, Captain Danton's Daughters, I 876.

A Treasure Lost. New York: Street and Smith (Eagle Series), I904. Second half of Silent and True; Or, A Little Queen. See Silent and True; Or, A Little Queen, I876-77.

Woman Without Mercy; Or, A Heart of Stone. New York: Street and Smith (Eagle Series), c. I904. Second half of $A$ Mad Marriage. See $A$ Mad Marriage, I874-75.

1906

A Wonderful Woman; Or, Rose O'Donnell's Secret. First half of $A$ Wonderful Woman. New York: Street and Smith, 1906. See $A$ Wonderful Woman, 1872.

1907

A Fateful Abduction; Or, The Secret Sorrow. New York: Dillingham, c. I907. See A Secret Sorrow, I879.

His to Love or Hate. New York: Street and Smith, 1907. See Lost For a Woman, I879-80.

1915

The Mystery of Bracken Hollow. Second half of $A$ Wonderful Woman. New York: Street and Smith, I9I 5. See $A$ Wonderful Woman, I872.

\section{Undated}

The Paths of Love; Or, A Leap in the Dark. London: James Henderson, n.d. See A Leap in the Dark; Or, Wedded Yet No Wife, I872-73.

Vivia, the Heiress of Castle Cliffe. London: James Henderson, n.d. See Victoria; Or, The Heiress of Castle Cliffe, r 862 (?). 